\section{'NABIO808' (Syn. 'NAROBAN5'): A tasty cooking banana cultivar with resistance to pests and diseases}

\section{Robooni Tumuhimbise $^{1 *}$, Henry Buregyeya ${ }^{1}$, Jerome Kubiriba ${ }^{1}$, Wilberforce K. Tushemereirwe ${ }^{1}$, Alex Barekye ${ }^{2}$, Reuben \\ S. Tendo ${ }^{3}$, Betty Namagembe ${ }^{1}$, Sedrach Muhangi ${ }^{1}$, Francis Kazigye $^{1}$, David Talengera ${ }^{1}$, Jimmy Tindamanyire ${ }^{1}$, Kenneth Akankwasa ${ }^{1}$, Gertrude Nabulya ${ }^{1}$, Josephine Namaganda ${ }^{1}$, Waswa William ${ }^{1}$, Abias Kushaba ${ }^{1}$, Mary Namuddu ${ }^{1}$, Naboth Oyesigye $^{1}$, Priver Namanya ${ }^{1}$, Ivan K. Arinaitwe ${ }^{1}$, Allan Waniale ${ }^{1}$, Deborah Karamura ${ }^{4}$ and Eldad Karamura ${ }^{4}$}

\begin{abstract}
NABIO808' is a newly released, conventionally-bred triploid cooking banana cultivar in Uganda. It produces an average bunch yield of $54.5 \mathrm{t} \mathrm{ha}$ $\mathrm{yr}^{-1}$ and is resistant to weevils, nematodes, and black Sigatoka. Additionally, its food is yellow, soft, and tasty, like that of most preferred landrace cultivars, making it more acceptable to end-users.
\end{abstract}

Keywords: Matooke breeding, host plant resistance, weevils, nematodes, black Sigatoka

\section{INTRODUCTION}

Banana (Musa spp.), a giant, heterogeneous, herbaceous, perennial, and vegetatively-propagated plant, is an important food and cash crop grown worldwide (FAOSTAT 2017). It is considered a staple food crop that significantly contributes to the caloric intake of low-income subsistence farmers in developing countries (Brown et al. 2017). In Uganda, bananas, especially the East African highland cooking banana (EAHCB) cultivars, occupy the third largest cultivated area among staple food crops (FAOSTAT 2017) and are grown by more than $75 \%$ of the farmers. Although the EAHCB cultivars are important, their yields in farmers' fields in Uganda are less than $30 \%$ of their potential. Furthermore, their longevity in planted fields in some areas of Uganda, especially in the lowlands of the Eastern and Central regions, has declined considerably to less than five years (Tushemereirwe et al. 2001).

The leading cause of reduced banana yield and longevity in planted fields is the susceptibility of local banana cultivars to the banana weevil (Cosmopolites sordidus (Germar), burrowing nematodes, and black Sigatoka (Gold et al. 2004; Tushemereirwe et al. 2001). This poses a serious threat to the future sustainability of banana production and may further destabilize food security and household incomes across the East African region.
Crop Breeding and Applied Biotechnology 19(4), 491-495, 2019 Brazilian Society of Plant Breeding. Printed in Brazil http://dx.doi.org/10.1590/198470332019v19n4c71

\footnotetext{
*Corresponding author: E-mail: rtumuhimbise@hotmail.com (iD) ORCID: 0000-0002-4188-1858
}

Received: 09 May 2019 Accepted: 07 August 2019

${ }^{1}$ National Banana Research Programme, Kampala, Uganda

${ }^{2}$ Zonal Agricultural Research and Development Institute, Kachwekano, Kabale, Uganda ${ }^{3}$ International Potato center, Kumasi, Ghana

${ }^{4}$ Bioversity International, Uganda Office, Kampala, Uganda 


\section{$R$ Tumuhimbise et al.}

One of the most appropriate and cost effective interventions currently used in Uganda to address the banana pest and disease challenge is developing resistant banana cultivars. Resistant cultivars offer enormous spill-over benefits for human health and have positive environmental impacts (Sharm and Ortiz 2002; Silva et al. 2001). This article presents the development process, agronomic performance, and attributes of a newly released cooking banana cultivar in Uganda ('NABIO808') that was developed with the aim of improving bunch yield and resistance to weevils, nematodes, and black Sigatoka. The cultivar was evaluated under code 'NABIO808' and later released as NAROBAN5 by the Ugandan Ministry of Agriculture, Animal Industry and Fisheries (MAAIF) in April 2019.

\section{PEDIGREE, BREEDING, AND EVALUATION METHODS}

'NABIO808' is a secondary triploid cooking banana cultivar (AAA) derived from an interploidy cross between the tetraploid hybrid '660K-1' AAAA (derived from 'Enzirabahima' AAA x 'Calcutta 4' AA) with a matooke improved diploid '1345K-1' AA (derived from 'Nakawere' AAA x 'Calcutta 4' AA). Embryos extracted from hybrid seeds of this cross, together with those of other banana crosses made during 2008, were separately cultured in vitro as described by Uma et al. (2011). Three-hundred hardened seedlings pooled from all crosses were established in a single-site, non-replicated, research-station early-evaluation trial at the National Agricultural Research Laboratories (NARL) - Kawanda in Uganda from 2009 to 2012. Eleven cooking-type triploid banana hybrids identified by flow cytometry (Nsabimana and van Staden 2006), with resistance to black Sigatoka [selected according to Orjeda (1998)], pendent bunches, and a bunch weight of $\geq 10 \mathrm{~kg} \mathrm{plant}^{-1}$, were selected and multiplied in vitro for further evaluation in replicated, multi-location preliminary yield trials (PYTs) from 2013 to 2015.

In the PYTs, genotypes were evaluated for bunch yield (BYL); responses to black Sigatoka, weevils, and nematodes; and consumer acceptability. Consequently, two promising hybrids ('NABIO808' and 'NABIO306') that combined high BYL ( $\geq 30 \mathrm{t} \mathrm{ha}^{-1} \mathrm{yr}^{-1}$ ); resistance to black Sigatoka, weevils, and nematodes; and high-quality fruit attributes were selected for advancement to on-farm trials. The two genotypes selected ('NABIO808' and 'NABIO306'), together with two most market-preferred landrace cultivars (Kibuzi and Mbwazirume), were established in seven regional on-farm trials. The trial locations were Mbarara (lat $0^{\circ} 36^{\prime} 16^{\prime \prime} \mathrm{S}$, long $30^{\circ} 38^{\prime} 54^{\prime \prime} \mathrm{E}$, alt $1422 \mathrm{~m}$ asl), Bushenyi (lat $0^{\circ} 32^{\prime} 13^{\prime \prime} \mathrm{S}$, long $30^{\circ} 11^{\prime} 08^{\prime \prime} \mathrm{E}$, alt $1607 \mathrm{~m}$ asl), Fort Portal (lat $0^{\circ} 39^{\prime} 42^{\prime \prime} \mathrm{N}$, long $30^{\circ} 16^{\prime} 29^{\prime \prime} \mathrm{E}$, alt $1518 \mathrm{~m}$ asl), Hoima (lat $1^{\circ} 25^{\prime} 38.478^{\prime \prime} \mathrm{N}$, long $31^{\circ} 20^{\prime}$ 54.402" $\mathrm{E}$, alt $1131 \mathrm{~m}$ asl), Jinja (lat $0^{\circ} 26^{\prime} 20^{\prime \prime} \mathrm{N}$, long $33^{\circ} 12^{\prime} 11^{\prime \prime} \mathrm{E}$, alt $1187 \mathrm{~m}$ asl), Kamuli (lat $0^{\circ} 56^{\prime} 49^{\prime \prime} \mathrm{N}$, long $3^{\circ} 07^{\prime}$ $10^{\prime \prime} \mathrm{E}$, alt $1120 \mathrm{~m}$ asl), and Kawanda (lat $0^{\circ} 25^{\prime} 14^{\prime \prime} \mathrm{N}$, long $32^{\circ} 32^{\prime} 26^{\prime \prime} \mathrm{E}$, alt $1300 \mathrm{~m}$ asl), and plants were evaluated for two ratoon crop cycles from 2016 to 2018. 'Yangambi-KM5', a local check cultivar resistant to weevils and nematodes, was included in the NARL-Kawanda trial as the only site that was designated for weevil and nematode assessment. Kawanda is a hotspot for banana weevils, nematodes, and black Sigatoka. The seven trial sites represented the major banana-growing areas in Uganda and are located in three diverse agro-ecological zones (Wortmann and Eledu 1999).

On-farm trials were established using 2.5-month-old tissue culture plants of each genotype planted at a spacing of $3 \mathrm{~m}$ by $3 \mathrm{~m}$ within and between rows, for a plant population density of 1111 plants/ha. At planting, about $7 \mathrm{~kg}$ of well decomposed cow dung manure were applied to each hole. Trials were laid out in a randomized complete block design with three replications. Blocks were surrounded by 'Mbwazirume', a check cultivar susceptible to black Sigatoka, weevils, and nematodes. No supplemental irrigation was applied, and the trials were regularly weeded, de-trashed and de-suckered to ensure a suitable environment for banana plant growth.

Bunch yield and its components [total number of hands (TNH), fruit length (FL), and fruit circumference (FC)] were assessed at harvest, whereas the plant growth traits [plant height (PH), plant girth (PG), and number of green functional leaves (NFL)] were assessed at flowering. The genotype response to black Sigatoka infection was also assessed at flowering using the index of non-spotted leaf (INSL) (Orjeda 1998). Banana cultivars with an INSL of $\geq 70 \%$ are resistant, according to Orjeda (1998). Their response to weevil damage was assessed according to Twesigye et al. (2018), whereas response to nematodes was assessed according to Dochez et al. (2005).

In order to select the banana cultivar with acceptable end-user fruit quality attributes, consumer acceptance tests of the cooked food of the genotypes were performed by 465 banana farmers ( 264 women and 201 men) from all seven trial sites. The tests were based on five sensory attributes: taste, aroma, mouth feel, colour, and general acceptability - using a scale of 1 to 6 , where 1 = dislike extremely, $2=$ dislike, $3=$ like fairly, $4=$ like, $5=$ like very much, and $6=$ like extremely. 
'NABIO808' (Syn. 'NAROBAN5'): A tasty cooking banana cultivar with resistance to pests and diseases

All the data collected across seven trial sites and two ratoon crop cycles were averaged and analysed using GenStat, version 14 (Payne et al. 2011). Trait means were separated using least significance differences at $\mathrm{P}<0.05$ (Payne et al. 2011).

\section{PERFORMANCE CHARACTERISTICS}

Genotypes were significantly different for most of the traits assessed (Tables 1, 2, and 3). The highest mean performance for BYL, TNH, FC, PG, NFL, and INSL across sites and crop cycles was recorded for 'NABIO808' (Table 1). 'NABIO306', however, recorded the highest FC (Table 1). For short plant height, 'NABIO808' emerged as the second best cultivar, after 'NABIO306' (Table 1). Shorter banana plants $(\leq 300 \mathrm{~cm}$ ) are more desirable than taller ones because taller plants are more prone to wind damage. Generally, for all the agronomic traits assessed, except FL, 'NABIO808' emerged as the best cultivar. It also exhibited the highest level of resistance to black Sigatoka, one of the key banana breeding targets of the National Agricultural Research Organisation (NARO) in Uganda. Its INSL, the measure of resistance to black Sigatoka, was $76.4 \%$. Orjeda (1998) revealed that bananas require more than $70 \%$ of active leaf foliage at flowering for proper development and filling of their fruits. Severe infestation of bananas with black Sigatoka, a fungal disease, caused by Mycosphaerella fijiensis (Morelet), can lead to a considerable reduction in the photosynthetic leaf area of the plant. Consequently, bunches and fruits of infected plants produce lower bunch weight in comparison to those of healthy banana plants (Arzanlou et al. 2007). Vuylsteke et al. (1993) revealed that resistance to black Sigatoka results from the interaction between a major recessive gene and two modifiers with additive effects.

Host plant resistance of 'NABIO808' to weevils and nematodes was higher than that of the landrace cultivars ('Mbwazirume' and 'Kibuzi') and 'NABIO306' but closest to that of 'Yangambi-KM5', a check cultivar resistant to weevils and nematodes (Table 2), indicating that 'NABIO808' is a cultivar resistant to weevils and nematodes. The host plant resistance of 'NABIO808' to weevils and nematodes was not significantly different ( $\mathrm{P}>0.05)$ from that of 'YangambiKM5'. Banana host plant resistance to weevils and nematodes is likewise a pertinent breeding objective of NARO.

Table 1. Mean performance of four cooking banana cultivars evaluated for eight traits across seven sites and two crop cycles from 2016 to 2018

\begin{tabular}{|c|c|c|c|c|c|c|c|c|}
\hline \multirow[b]{2}{*}{ Genotypes } & \multicolumn{8}{|c|}{ Traits } \\
\hline & $\begin{array}{c}\text { BYL } \\
\left(\mathrm{t} \mathrm{ha}^{-1} \mathrm{yr}^{-1}\right)\end{array}$ & TNH & $\begin{array}{l}\mathrm{FC} \\
(\mathrm{cm})\end{array}$ & $\begin{array}{c}\mathrm{FL} \\
(\mathrm{cm})\end{array}$ & $\begin{array}{l}\mathrm{PH} \\
(\mathrm{cm})\end{array}$ & $\begin{array}{c}\text { PG } \\
(\mathrm{cm})\end{array}$ & NFL & $\begin{array}{c}\text { INSL } \\
(\%)\end{array}$ \\
\hline NABIO808 (NAROBAN5) & 54.5 & 9.1 & 13.1 & 16.6 & 332.8 & 53.6 & 13.2 & 76.4 \\
\hline Kibuzi (local cultivar) & 45.6 & 8.7 & 13.0 & 16.4 & 384.3 & 46.7 & 9.5 & 66.2 \\
\hline Mbwazirume (local cultivar) & 34.0 & 8.3 & 12.3 & 15.2 & 333.5 & 51.7 & 8.2 & 56.3 \\
\hline F-Probability & $<0.001$ & $<0.001$ & 0.018 & 0.013 & $<0.001$ & $<0.001$ & $<0.001$ & $<0.001$ \\
\hline
\end{tabular}

$\mathrm{LSD}_{0.05}=$ least significant difference at $5 \%, \mathrm{BYL}=$ bunch yield, $\mathrm{TNH}=$ total number of hands, $\mathrm{FC}=$ fruit circumference, $\mathrm{FL}=\mathrm{fruit}$ length, $\mathrm{PH}=\mathrm{plant}$ height, $\mathrm{PG}=\mathrm{plant}$ girth, $\mathrm{NFL}=$ number of green functional leaves, and INSL = index of non-spotted leaf.

Table 2. Mean performance of five banana cultivars for percentage of total cross-sectional damage to corm by weevils and root necrosis by nematodes across two ratoon crop cycles at NARL-Kawanda from 2016 to 2018

\begin{tabular}{lcc}
\hline Genotypes & Root necrosis by nematodes (\%) & Total cross-sectional damage to corm by weevils (\%) \\
\hline NABIO808 ('NAROBAN5') & 3.2 & 1.5 \\
NABIO306 & 3.5 & 1.7 \\
Yangambi-KM5 (resistant check) & 3.9 & 1.4 \\
Kibuzi (susceptible check) & 47.3 & 28.3 \\
Mbwazirume (susceptible check) & 62.3 & 49.4 \\
\hline MEAN & 24.0 & 16.5 \\
LSD $_{0.05}$ & 0.9 & 1.1 \\
F-Probability & $<0.001$ & $<0.001$ \\
\hline
\end{tabular}

$\mathrm{LSD}_{0.05}=$ least significant difference at $5 \%$ 
These pests greatly reduce yields and the longevity of bananas in planted fields in the banana growing communities in Uganda (Tushemereirwe et al. 2001; Gold et al. 2004), and are therefore a key breeding target of the Banana Breeding Programme of NARO in Uganda.

The sensory attributes of 'NABIO808' (taste, aroma, mouth feel, and colour) were consistently ranked closest to those of 'Mbwazirume' (Table 3). 'Mbwazirume' is one of the most consumer-preferred landrace cooking banana cultivars due to high quality attributes of its cooked food. It dominates the banana markets in Uganda and is therefore highly marketable.

Generally, 'NABIO808' is an agronomically superior banana cultivar, combining multiple resistances to weevils, nematodes, and black Sigatoka with high quality fruit attributes and stability across diverse environments in Uganda. Because of these pertinent qualities, 'NABIO808' is more acceptable to end-users. Akankwasa et al. (2013) clearly

Table 3. Mean performance of four green mature cooking banana cultivars for fruit quality attributes in sensory evaluations with participation of 465 banana farmers across seven sites and two cycles from 2016-2018

\begin{tabular}{|c|c|c|c|c|c|}
\hline \multirow[b]{2}{*}{ Genotype } & \multicolumn{5}{|c|}{ Cooked food sensory traits (Hedonic scale: 1-6) } \\
\hline & Taste & Aroma & Mouth feel & Colour & Overall Acceptability \\
\hline NABIO808 (NAROBAN5) & 5.60 & 5.35 & 5.65 & 5.90 & 5.70 \\
\hline NABIO306 & 5.55 & 5.25 & 5.45 & 5.85 & 5.55 \\
\hline Mbwazirume (local check cultivar) & 5.75 & 5.60 & 5.75 & 5.95 & 5.80 \\
\hline Kibuzi (local check cultivar) & 5.20 & 4.70 & 5.15 & 4.95 & 5.10 \\
\hline Mean & 5.53 & 5.23 & 5.50 & 5.66 & 5.54 \\
\hline
\end{tabular}

LSD 0.05 = least significant difference at 5\%, Hedonic scale: $1-6$, where 1 = dislike very much, 2 = dislike, $3=$ like fairly, $4=$ like, $5=$ like very much, and 6 = like extremely.

Table 4. Other characteristics (descriptors) of 'NABIO808'

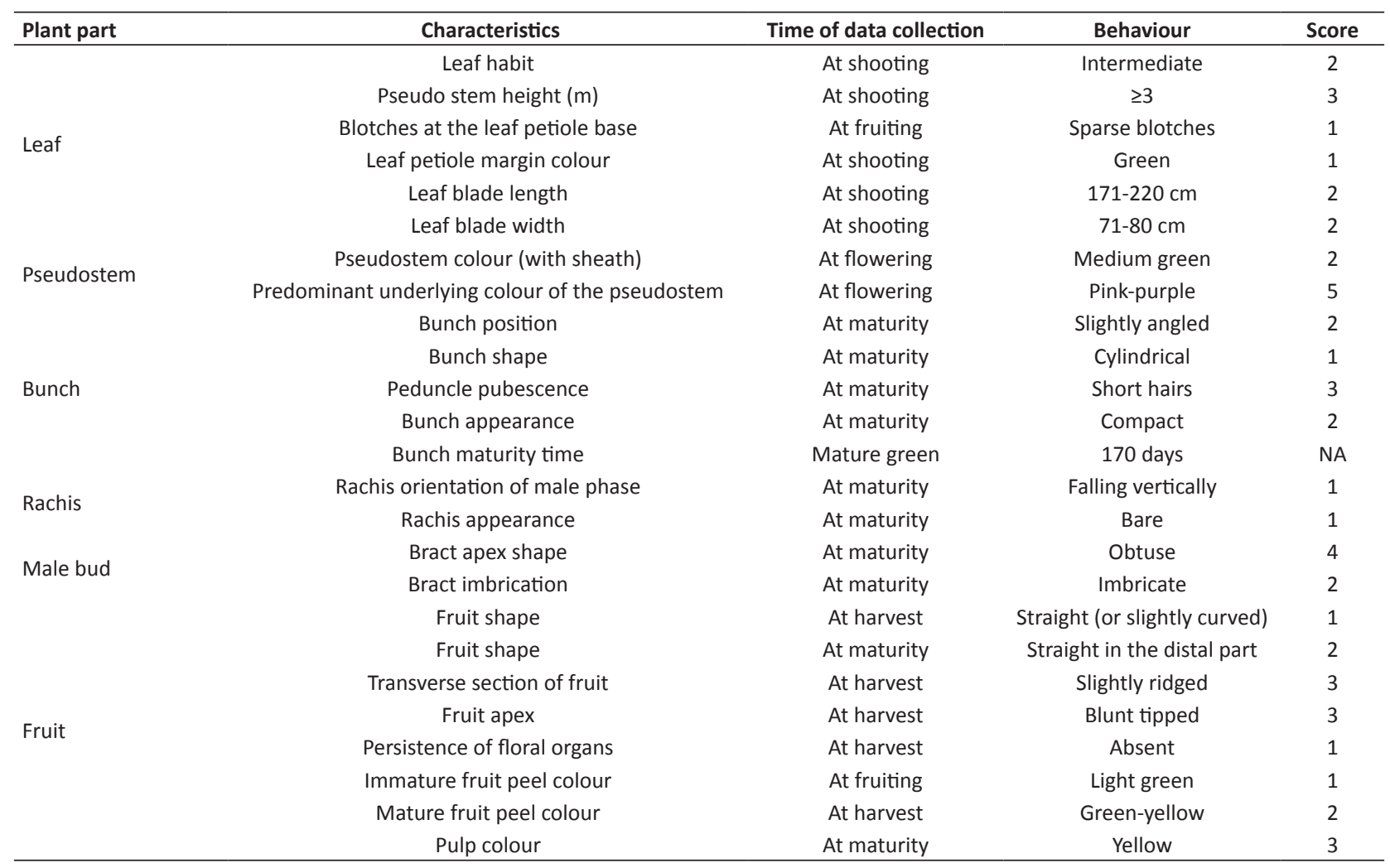


indicated that for a new banana cultivar to meet end-user needs, it must be balanced in terms of yield, pest and disease resistance, and quality attributes. Consequently, based on the recommendations of both farmers and the NARO scientists, 'NABIO808' was officially released as 'NAROBAN5' and added to the National Cultivar List by MAAIF in April 2019. 'NAROBAN' denotes the institution NARO that developed the cultivar.

\section{OTHER CHARACTERISTICS}

Supplemental characteristics that define 'NABIO808'are shown in Table 4.

\section{SEED PRODUCTION AND DISTRIBUTION}

'NABIO808' was officially released as 'NAROBAN5' and added to the National Cultivar List by MAAIF. As 'NAROBAN5' is a vegetatively propagated cultivar, it is currently maintained in research-station fields and in vitro by the National Banana Research Programme of NARO in Kawanda, Uganda. Planting materials (suckers and tissue culture plants) can be accessed through NARO and designated private tissue culture laboratories in the country.

\section{ACKNOWLEDGEMENTS}

The authors thank the Government of Uganda and Bioversity International for funding the research activities that culminated in the development and release of 'NABIO808' (Syn 'NAROBAN5').

\section{REFERENCES}

Akankwasa K, Ortmann GF, Wale E and Tushemereirwe WK (2013) Farmers' choice among recently developed hybrid banana varieties in Uganda: A multinomial logit analysis. Agrekon 52: 25-51.

Arzanlou M, Abeln EC, Kema GH, Waalwijk C, Carlier J, Vries Id, Guzmán M and Crous PW (2007) Molecular diagnostics for the Sigatoka disease complex of banana. Phytopathology 97: 1112-1118.

Brown A, Tumuhimbise $R$, Amah D, Uwimana B, Nyine $M$, Mduma $H$, Talengera D, Karamura D, Kubiriba J and Swennen R (2017) Bananas and plantains (Musa spp.). In Campos H and Caligari PDS (eds) Genetic improvement of tropical crops. Springer Nature, Switzerland, $p$. 219-240.

Dochez C, Whyte J, Tenkouano A, Ortiz R and De Waele D (2005) Response of East African highland bananas and hybrids to Radopholus similis. Nematology 7: 655-666

FAOSTAT (2017) FAOSTAT: Crops and products domain. Available at: $<$ http://www.fao.org/faostat/en/\#data/QC $\geq$. Accessed on May 1, 2019

Gold C, Kagezi G, Night G and Ragama P (2004) The effects of banana weevil, Cosmopolites sordidus, damage on highland banana growth, yield and stand duration in Uganda. Annals of Applied Biology 145: 263-269.

Nsabimana A and van Staden J (2006) Ploidy investigation of bananas (Musa spp.) from the National Banana Germplasm Collection at Rubona-Rwanda by flow cytometry. South African Journal of Botany 72: 302-305.

Orjeda G (1998) Evaluation of Musa germplasm for resistance to Sigatoka diseases and Fusarium wilt. Louma Productions, Montpellier, 63p.

Payne RW, Harding SA, Murray DA, Soutar DM, Baird DB, Glaser AI, Welham SJ, Gilmour AR, Thompson R and Webster R (2011) The guide to genstat release 14, part 2: statistics. VSN International, Hemel Hempstead, 1159p.

Sharm HC and Ortiz R (2002) Host plant resistance to insects: An ecofriendly approach for pest management and environment conservation. Journal of Environmental Biology 23: 111-35.

Silva SO, Souza Junior MT, Alves EJ, Silveira JRS and Lima MB (2001) Banana breeding program at Embrapa. Crop Breeding and Applied Biotechnology 1: 399-436

Tushemereirwe WK, Karamura D, Ssali H, Bwamiki D, Kashaija I, Nankinga C, Bagamba F, Kangire A and Sebuliba R (2001) Bananas (Musa spp). In Mukiibi KJ (ed) Agriculture in Uganda. Fountain Publishers, Uganda, p. 110-125.

Twesigye CK, Ssekatawa K, Kiggundu A, Tushemereirwe W, Matovu E and Karamura E (2018) Corm damage caused by banana weevils Cosmopolites sordidus (Germar) collected from different banana growing regions in Uganda. Agriculture and Food Security 7: 73

Uma S, Lakshmi S, Saraswathi MS, Akbar A and Mustaffa MM (2011) Embryo rescue and plant regeneration in banana (Musa spp.). Plant Cell, Tissue and Organ Culture 105: 105-111.

Vuylsteke D, Swennen R and Ortiz R (1993) Development and performance of black Sigatoka resistant tetraploid hybrids of plantain (Musa spp, $A A B$ group). Euphytica 65: 33-42.

Wortmann CS and Eledu CS (1999) Uganda's agroecological zones: a guide for planners and policy makers (online). Centro Internacional de Agricultura Tropical (CIAT), Kampala, 55p. (cc) $\mathrm{EY}$
use, distribution, and is an Open Access article distributed under the terms of the Creative Commons Attribution License, which permits unrestricted
in any medium, provided the original work is properly cited. 